\title{
WNT Family Protein
}

National Cancer Institute

\section{Source}

National Cancer Institute. WNT Family Protein. NCI Thesaurus. Code C20394.

Encoded by WNT Family Genes, secreted structurally related signaling WNT Family

Proteins are implicated in oncogenesis and in several developmental processes, including regulation of cell fate and embryonic patterning. $(\mathrm{NCl})$ 